INTER NATIONAL MONETARY FUND

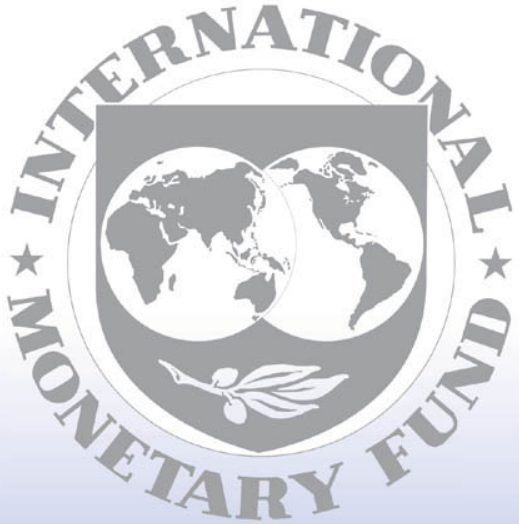

Staff

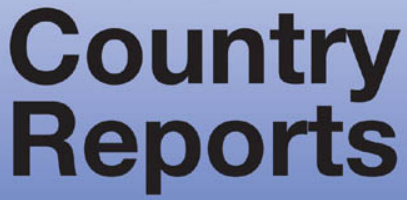




\section{Liberia: Enhanced Initiative for Heavily Indebted Poor Countries Initiative- Request for Additional Interim Assistance; and Press Release}

In connection with the Executive Board's consideration of Liberia's request for additional interim assistance under the Enhanced Heavily Indebted Poor Countries Initiative, the following documents have been released and are included in this package:

- $\quad$ The paper prepared by a staff team of the International Monetary Fund. It is based on the information available at the time when it was completed on February 26, 2010. The views expressed in this document are those of the staff team and do not necessarily reflect the views of Liberia or the Executive Board of the IMF.

- A Press Release summarizing the decision taken by the Executive Board to approve the request.

The policy of publication of staff reports and other documents by the IMF allows for the deletion of market-sensitive information.

Copies of this report are available to the public from

International Monetary Fund $\bullet$ Publication Services

700 19th Street, N.W. • Washington, D.C. 20431

Telephone: (202) 623-7430 • Telefax: (202) 623-7201

E-mail: publications@imf.org •Internet: http://www.imf.org

\section{International Monetary Fund Washington, D.C.}


INTERNATIONAL MONETARY FUND

LIBERIA

\section{Enhanced Initiative for Heavily Indebted Poor Countries Request for Additional Interim Assistance}

Prepared by the African Department

(In consultation with the Legal; Strategy, Policy, and Review; and Finance Departments)

Approved by: Seán Nolan and Dhaneshwar Ghura

February 26, 2010

1. On March 14, 2008, the Executive Board approved Liberia's HIPC Initiative decision point $^{1}$ and three-year arrangements under the Extended Credit Facility (ECF) ${ }^{2}$ and Extended Fund Facility (EFF). ${ }^{3}$ The Board also approved interim assistance in the amount of SDR 30.14 million for the period March 18, 2008-March 17, 2010. ${ }^{4}$

2. In the attached letter (Appendix I) the Liberian authorities request additional interim assistance under the HIPC Initiative to cover 100 percent of debt service to the IMF falling due between March 18, 2010, and March 17, 2011. ${ }^{5}$ Staff supports this request in light of Liberia's progress in debt rescheduling and solid program performance.

3. Liberia is making good progress on debt rescheduling. Sufficient assurances regarding enhanced HIPC Initiative assistance from Liberia's other creditors are in place. A

\footnotetext{
${ }^{1}$ IMF Country Report No. 08/106, March 2008.

${ }^{2}$ The arrangement was initially approved under the Poverty Reduction and Growth Facility (PRGF) but, as of January 7, 2010, all arrangements under the PRGF were renamed arrangements under the Extended Credit Facility.

${ }^{3}$ IMF Country Report No. 08/108, March 2008.

${ }^{4}$ On March 14, 2008, the Board approved interim assistance of SDR 15.03 million for 12 months starting March 18, 2008; Directors approved additional interim assistance of SDR 15.11 million for the period March 18, 2009-March 17, 2010.

${ }^{5}$ Eligible debt service is estimated at SDR 4.2 million, consisting of GRA charges and a small amount of ECF interest for the period January 1-7, 2010 (SDR 0.02 million) on GRA purchases and PRGT loans as of the date of the Decision Point (March 18, 2008) that remain outstanding. ECF interest will be zero for the remainder of 2010 and 2011. If the completion point is reached before March 17, 2011, any unused balances in the Umbrella Account for the benefit of Liberia will be delivered to Liberia as part of the completion point assistance.
} 
donor-financed buyback operation of US\$1.2 billion commercial debt at a discount of nearly 97 percent of face value was completed in April 2009. Bilateral agreements have been signed with all Paris Club creditors except Switzerland. The authorities are committed to reaching agreements with remaining official non-Paris Club creditors holding debt of US\$129 million and creditors that did not participate in the April 2009 buyback operation holding US\$21 million of commercial debt.

4. Performance under the ECF-supported program is solid. The third ECF review was completed on a lapse of time basis on December 18, 2009. ${ }^{6}$ All but one of the quantitative performance criteria (PC) for the end-June 2009 test date were observed. The PC on total revenue collection was not observed but the deviation was temporary and did not jeopardize program objectives. Structural reform commitments were largely met, though some with delays.

\section{Liberia aims to reach the completion point in mid-2010 with continued strong} efforts on outstanding triggers. To avoid delays in reaching the completion point, the authorities need to move forcefully to: (1) deepen implementation of the Public Financial Management Act; (2) secure passage of the Investment Act; (3) complete second-round audits of five key ministries; (4) finish regularizing the Education Ministry payroll; and (5) complete the review of Poverty Reduction Strategy implementation in the last fiscal year.

\section{Liberia's Umbrella Account balance from the interim assistance approved for} previous periods stands at SDR 12 million as of February 2010. This unused balance is the result of lower than projected SDR interest rates and related GRA charges, and is expected to be more than sufficient to cover Liberia's eligible debt obligations for the coming year, which are estimated at SDR 4.2 million. Therefore, no additional transfers to the Umbrella Account are needed at this stage.

7. A draft decision approving interim assistance to Liberia for the period March 18, 2010 through March 17, 2011 and authorizing the use for this purpose of unused balances in the HIPC Umbrella Account for the benefit of Liberia is attached for Directors' consideration. The decision is proposed for adoption on a lapse of time basis.

\footnotetext{
${ }^{6}$ IMF Country Report No. 09/332, December 2009.
} 
APPENDIX I

Monrovia, February 25, 2010

Mr. Dominique Strauss-Kahn

Managing Director

International Monetary Fund

Washington, DC 20431

Dear Mr. Strauss-Kahn:

On behalf of the Republic of Liberia, we request interim assistance to cover all of Liberia's eligible debt service to the International Monetary Fund (IMF) that falls due between March 18, 2010, and March 17, 2011.

The Executive Board of the IMF completed the third review of the Arrangement under the Extended Credit Facility (ECF) for Liberia on a lapse of time basis on December 18, 2009. The program remains on track. All performance criteria (PC) for end-June 2009 were met except the PC on total revenue collection. That deviation was, however, temporary and did not jeopardize key program objectives. Structural reform commitments were largely met, albeit some with delays.

We are making a concerted effort to meet the floating completion point triggers for the enhanced HIPC Initiative, with the aim of reaching the completion point in 2010 . We anticipate that the fourth review can be completed by June 2010. We remain fully committed to implementing our ECF-supported economic program.

Sincerely yours,

$/ \mathrm{s} /$

Augustine Ngafuan

Minister of Finance
$/ \mathrm{s} /$

Joseph Mills Jones

Governor, Central Bank of Liberia 
Press Release No. 10/100

FOR IMMEDIATE RELEASE

March 19, 2010
International Monetary Fund

Washington, D.C. 20431 USA

\section{IMF Executive Board Approved Additional Interim Assistance Request Under the Enhanced HIPC Initiative for Liberia}

The Executive Board of the International Monetary Fund granted additional interim assistance under the enhanced Heavily Indebted Poor Countries (HIPC) Initiative in an amount equivalent to SDR 4.2 million (about US\$6.4 million) for the period March 18, 2010 through March 17, 2011 on a lapse of time basis. ${ }^{1}$

On March 14, 2008, the Executive Board approved Liberia's HIPC Initiative decision point and three-year arrangements under the Extended Credit Facility (ECF) ${ }^{2}$ and Extended Fund Facility (see Press Release No 08/52). The Board also approved interim assistance in the amount of SDR 30.14 million for the period March 18, 2008-March 17, 2010.

The third ECF review was completed on December 18, 2009 (see Press Release No. 09/469) and performance under the ECF-supported program is solid. Liberia is making good progress on debt rescheduling, aiming to reach the completion point in mid-2010 with continued strong efforts.

Interim assistance under the enhanced HIPC Initiative is debt relief granted on its debt service falling due between the HIPC decision and completion points. Once it reaches the HIPC completion point, a country is allowed to receive the full debt relief committed at decision point.

\footnotetext{
${ }^{1}$ The Executive Board takes decisions under its lapse of time procedure when the Board agrees that a proposal can be considered without convening formal discussions.

${ }^{2}$ The arrangement was initially approved under the Poverty Reduction and Growth Facility (PRGF) but, as of January 7, 2010, all arrangements under the PRGF were renamed arrangements under the Extended Credit Facility.
} 